\title{
Plant-rodent interactions after a heavy snowfall decrease plant regeneration and soil carbon emission in an old-growth forest
}

\author{
Qingqiu Zhou ${ }^{1,2}$, Debao $\mathrm{Li}^{1,2}$, Shangwen $\mathrm{Xia}^{3}$, Zhe Chen ${ }^{1,2}$, Bo Wang ${ }^{4^{*}}$ and Jianping $\mathrm{Wu}^{1,2^{*}}$ (D)
}

\begin{abstract}
Background: Climate extremes are likely to become more common in the future and are expected to change ecosystem processes and functions. As important consumers of seeds in forests, rodents are likely to affect forest regeneration following an extreme weather event. In April 2015, we began a field experiment after an extreme snowfall event in January 2015 in a primary forest that was > 300 years old. The heavy snow broke many tree limbs, which presumably reduced the numbers of seeds produced. Two treatments (rodent exclusion and rodent access) were established in the forest, in which rodent exclusion were achieved by placing stainlessness nets around the plot borders. Plant abundance, plant species richness, soil properties, soil microbial community composition, basal and substrate-induced respiration were determined in December 2017.

Results: Plant abundance and species richness significantly increased, but soil microbial biomass decreased with rodent exclusion. Urease activity and soil basal respiration also significantly decreased with rodent exclusion. Most other soil properties, however, were unaffected by rodent exclusion. The relative effects of multiple predictors of basal respiration were mainly explained by the composition of the soil microbial community.

Conclusions: After a heavy snowfall in an old-growth forest, exclusion of rodents increased plant regeneration and reduced microbial biomass and soil basal respiration. The main factor associated with the reduction in soil basal respiration was the change in the composition of the soil microbial community. These findings suggest that after a heavy snowfall, rodents may interfere with forest regeneration by directly reducing plant diversity and abundance but may enhance carbon retention by indirectly altering the soil microbial community.
\end{abstract}

Keywords: Climate extreme, PLFAs, Soil respiration, Forest ecosystem, Enzyme activity

\section{Introduction}

Forests cover about 4 billion ha worldwide and provide important ecosystem goods and functions (Fei et al. 2018; Jactel et al. 2018; Keenan et al. 2015). In particular, the net global forest carbon sink was estimated to be 1.1

\footnotetext{
* Correspondence: yangblue@ahu.edu.cn; jianping.wu@ynu.edu.cn

${ }^{4}$ School of Resources and Environmental Engineering, Anhui University, Hefei 230601, China

'Yunnan Key Laboratory of Plant Reproductive Adaptation and Evolutionary Ecology, Yunnan University, Kunming 650500, China

Full list of author information is available at the end of the article
}

Pg.year ${ }^{-1}$, with the largest uncertainties in tropical forests (Pan et al. 2011). Because primary forests account for more than one-third of the total forest area on the planet and because tropical/subtropical forests represent nearly half of the primary forest area (Luyssaert et al. 2008; Morales-Hidalgo et al. 2015), understanding the carbon dynamics in tropical/subtropical primary forests is important. Climate extremes (such as droughts, heatwaves, and rainstorms) are expected to become more common in the future (Kayler et al. 2015; Reyer et al. 2015). Although the high productivity and biodiversity 
of primary forests may help mitigate climate change and climate extremes (Stephenson et al. 2014; Zhou et al. 2006), our understanding of the responses of above- and belowground properties to climate extremes remains limited in primary forest ecosystems.

Among the climate extremes, extreme snowfall events are likely to have substantial effects on forest ecosystems (Ashley et al. 2020; Zhao et al. 2016). Previous relevant studies mainly focused on boreal and temperate forests because such forests frequently experience heavy snow loads in the winter (Ashley et al. 2020; Venalainen et al. 2020). Heavy snowfall, for example, frequently causes substantial damage (including the breaking of stems and uprooting of trees) in Finnish forests (Lehtonen et al. 2016). In boreal forests, a snowfall mass of $20-40 \mathrm{~kg} \cdot \mathrm{m}^{-2}$ is sufficient to break the stems of Scots pine and Norway spruce (Peltola et al. 1997). Forest canopies composed of mixed tree species are apparently more vulnerable to snow damage than forest canopies composed of one tree species (Diaz-Yanez et al. 2017). In addition, the snowpack in winter can also change soil carbon emission by affecting soil temperature and moisture (Contosta et al. 2016). Consistent with the latter result, a meta-analysis revealed that an increase in snowpack depth can increase soil respiration and microbial biomass by increasing soil temperature and water content ( $\mathrm{Li}$ et al. 2016).

For subtropical forest ecosystems, snowstorms are rare but can occur given climate change (Zhao et al. 2016; Zhou et al. 2013). An anomalous extreme snow storm in 2008 caused a substantial disturbance to subtropical forest ecosystems (Zhou et al. 2013). After another snow storm in a subtropical forest, researchers found that tree mortality exceeded seed recruitment and that evergreen broad-leaved species were more susceptible than deciduous broad-leaved species (Ge et al. 2015). In addition, snow storms can enhance canopy gaps that facilitate light penetration to the forest floor and thereby increase germination and invasion by non-native herbaceous species (Song et al. 2017b). By increasing the sizes of canopy gaps in another subtropical forest, snow storms also decreased soil organic carbon and nutrient contents (Xu et al. 2016). Using an eddy covariance technique, researchers recently found that, although a snow storm strongly decreased the carbon sink in a primary subtropical forest (Song et al. 2017a), the net carbon uptake was quickly restored in the following year, suggesting that forest ecosystems are highly resilient in their responses to extreme weather events (Reyer et al. 2015; Song et al. 2017a). These previous studies have demonstrated that extreme weather events can greatly affect above- and belowground organisms and processes (Bardgett and Caruso 2020; Bardgett and van der Putten 2014). Understanding those factors may increase our understanding of above- and belowground food webs, including the relationships among predators, plants, and soil functions (Mundim and Bruna 2016; Sitters and Venterink 2015).

Mammalian herbivores can affect soil nutrient cycling by grazing on aboveground plant tissues in grassland ecosystems (Bardgett and Wardle 2003). How climate change-driven alterations in the relationships between plants and herbivores/"seed predators", i.e., animals that consume seeds, can affect soil carbon and nutrients in forest ecosystems is still unclear. In primary forests, regeneration and recruitment of plants were strongly regulated by the activities of scatter-hoarding rodents, who can damage seedlings and can eat, remove, and cache plant seeds (Boone and Mortelliti 2019; Cao et al. 2016; Wang et al. 2013a, b). When snow storms decreased seed production, seed predators may alter its feeding preference and thereby substantially influence seed dispersal (Zhou et al. 2013). The changes in the interactions between seeds and seed predators induced by climate extremes may also affect soil microbial communities and soil carbon emission in primary forest ecosystems (Mundim and Bruna 2016). If these interactions increase soil carbon emissions, they could result in a positive feedback loop between soil carbon emissions and climate change.

In the present study, we conducted a field experiment with two treatments in April 2015 after an extreme snowfall event in January 2015. The extreme snowfall event was the largest record during past 40 years, which covered half-meter on the floor (Song et al. 2017b). The experimental site was a primary subtropical evergreen broadleaved forest that was $>300$ years old (Tan et al. 2011). The treatments ( \pm rodent exclusion) were applied to the replicated plots. As described in a conceptual diagram (Fig. 1), we hypothesized that exclusion of rodents would increase plant abundance and plant species richness, which would increase carbon input into the soil in the form of litter and rhizodeposition; the increased carbon input would increase soil carbon content but would also increase soil microbial activity and biomass, which would increase soil carbon emissions.

\section{Materials and methods}

\section{Study site}

The experiment was conducted at the Ailaoshan National Nature Reserve $\left(101^{\circ} 01^{\prime} \mathrm{E}, 2^{\circ} 32^{\prime} \mathrm{N}, 2450 \mathrm{~m}\right.$ a.s.l.), Yunnan Province, Southwestern China. The area has a typical subtropical monsoon climate, with a mean annual precipitation of $1840 \mathrm{~mm}$ and a mean annual temperature of $11.3^{\circ} \mathrm{C}$. The forest has a loamy alfisol. As noted earlier, the evergreen broadleaved forest in this study was $>300$ year old and occupied a protected area of 5110 ha. The average tree height was $20 \mathrm{~m}$, and the average tree density was 2728 per ha. The mean soil organic carbon content was $116 \mathrm{~g} \cdot \mathrm{kg}^{-1}$; the mean soil total 


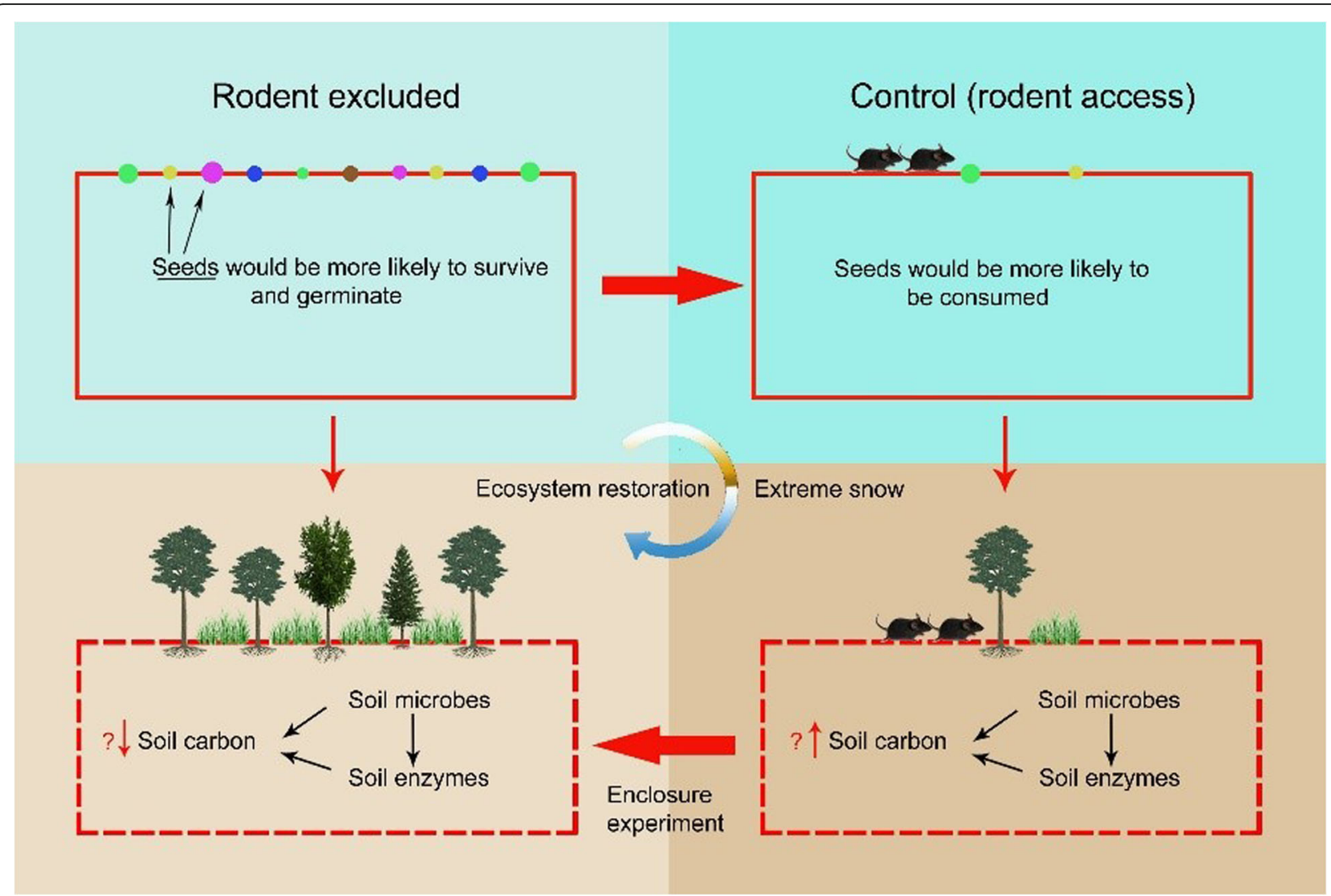

Fig. 1 A conceptual diagram showing how exclusion of rodents could decrease soil carbon emissions in a sub-tropical forest. We hypothesized that more seeds in soil would remain and geminate in plots without than with rodents because rodents consume seeds. The colored circles along the top sides of the upper rectangles represent the plant species whose seeds would survive predation by rodents. As a consequence of rodent exclusion, more seeds of more species would germinate following an extreme weather event (a heavy snowfall), resulting in sustained inputs of carbon to the soil via litter and rhizodeposition and the maintenance of soil carbon pools (bottom left rectangle). If rodents are not excluded, fewer seeds of fewer species would germinate following a heavy snowfall, resulting in a decrease of carbon inputs into soil and a decrease of soil carbon pools (bottom right rectangle)

nitrogen content was $7 \mathrm{~g} \cdot \mathrm{kg}^{-1}$; and the mean soil $\mathrm{pH}$ was 4.2. The dominant tree species included Castanopsis rufescens, Castanopsis wattii, Hartia sinensis, Lithocarpus chintungensis, Lithocarpus hancei, Lithocarpus xylocarpus, and Vaccinium ducluoxii (Song et al. 2017a; Tan et al. 2011). The dominant rodent species included Apodemus draco, Apodemus latronum, and Niviventer fulvescens. An anomalous extreme snowfall event occurred in January 2015; it resulted in a snow depth on the forest floor of $50 \mathrm{~cm}$. It also caused substantial damage to tree limbs and branches, and a substantial increase in the openness of the canopy (Song et al. 2017b).

\section{Experimental design}

We began the experiment in April 2015 at which time the primary forest had experienced 3 months with a substantial snowpack following the heavy snow in January. We randomly selected 24 pairs of plots (a total of 48 plots) from established 194 pairs of circular field plots, each measuring $1.3 \mathrm{~m}$ in diameter. Rodent exclusion plots were surrounded with a stainless steel mesh that was $1.3 \mathrm{~m}$ in height above ground and that extended 10 $\mathrm{cm}$ into the soil. The 1-cm openings in the mesh were sufficient to exclude rodents but presumably had minimal effects on light, air, and moisture penetration. Rodent "access" plots were not surrounded with stainless steel mesh and were adjacent to rodent exclusion plots. Each pair of plots ( \pm mesh, i.e., \pm rodent exclusion) represented one replicate. The two plots in a replicate were less than $1 \mathrm{~m}$ apart, and replicate pairs were separated by $\geq 10 \mathrm{~m}$ and were randomly arranged under the forest canopy as shown in Supplementary Material Figure S1.

Plant properties, soil properties, and microbial properties were assessed in December 2017. For plant properties, we determined the species of all woody plants taller than $5 \mathrm{~cm}$ within a $1 \mathrm{~m} \times 1 \mathrm{~m}$ subplot in each plot; the data were used to determine plant richness and plant abundance in plots with and without rodent exclusion. In addition, three soil cores (3-cm diameter) were collected at depths of $0-10 \mathrm{~cm}$; the cores were collected 
from the center of each plot to account for any heterogeneity resulting from position. Plant litter was removed from the soil surface before the cores were taken. The three cores were combined to form one composite soil sample per plot. Fresh soils were passed through a 2$\mathrm{mm}$ sieve, and remaining roots and stones were removed by hand. Soil samples were divided in half; one half was used for determination of soil physico-chemical characteristics, and the other half was used for phospholipid fatty acid (PLFA) analysis.

For physico-chemical analyses, soil samples were air dried, ground, and passed through a $0.25-\mathrm{cm}$ sieve. Soil water content was measured by comparing weights before and after oven-drying at $105^{\circ} \mathrm{C}$ for $24 \mathrm{~h}$. Soil $\mathrm{pH}$ was determined using a 1:2.5 ratio of soil mass to deionized water volume. Soil organic carbon and dissolved organic carbon (after extraction with $0.5 \mathrm{~mol} \cdot \mathrm{L}^{-1} \mathrm{~K}_{2} \mathrm{SO}_{4}$ ) were measured with an elemental analyzer (vario TOC, Elementar Analysensysteme GmbH, Langenselbold, Germany). Total soil nitrogen was measured after micro-Kjeldahl digestion (CleverChem380, DeChemTech. GmbH, Hamburg, Germany). Soil nitrate and ammonium concentrations were determined with a chemical analyzer (CleverChem380, DeChem-Tech. GmbH, Hamburg, Germany) after digestion in $1 \mathrm{~mol} \cdot \mathrm{L}^{-1} \mathrm{KCl}$. The activities of cellulase, sucrose, and urease were measured using a modified fluorescent-linked substrate microplate protocol with the situ soil $\mathrm{pH}$ conditions and the laboratory temperature (Liu 1996).

Soil microbial communities as indicated by PLFAs were examined as described by (Frostegård and Bååth 1996). Different PLFAs were used to represent different groups of soil microorganisms. Bacterial PLFAs were represented by i15:0, a15:0, 15:0, i16:0, 16:1 $\omega 9$, i17:0,

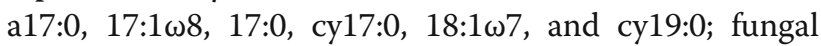
PLFAs were represented by the PLFAs $18: 1 \omega 9,18: 2 \omega 6$,

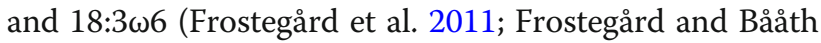
1996). The ratio of fungal PLFAs to bacterial PLFAs (F: B) was used to estimate the microbial community composition in soil (Bardgett et al. 1996). All of the PLFAs were indicated by MIDI peak identification software (MIDI, Inc., Newark, DE, USA).

Soil basal respiration and substrate-induced respiration were measured with a microcosm experiment modified from Wardle and Zackrisson (2005). In brief, a 5-g (dry weight) subsample of fresh soil from each of 12 randomly selected plots with and without rodent exclusion was placed in a 228$\mathrm{mL}$ glass bottle, and the soil moisture was adjusted to $100 \%$ of water holding capacity to eliminate water limitation. For each treatment ( \pm rodent exclusion), 6 bottles were amended with $5 \mathrm{mg}$ of glucose and 6 bottles were not amended with glucose. The bottles were sealed and incubated at room temperate $\left(25^{\circ} \mathrm{C}\right)$. After 0 and $2 \mathrm{~h}$ of incubation, headspace $\mathrm{CO}_{2}$ concentration was measured with a gas chromatograph (GC2014, Shimadzu, Japan).

\section{Statistical analyses}

T-test was used to determine the effect of rodent exclusion on plant properties, soil properties, soil enzymes, and soil microbial community with stats package in $\mathrm{R}$. The normality and heterogeneity were tested before $\mathrm{T}$ test. Data was made a Log-transformation when data did not fit the standard. Multiple regression models were used to determine the total effects of plants (species richness and abundance), soil enzyme activity (urease, sucrose, and cellulase), soil properties (soil organic carbon, soil total nitrogen, $\mathrm{NO}_{3}{ }^{-}-\mathrm{N}, \mathrm{NH}_{4}{ }^{+}-\mathrm{N}, \mathrm{pH}$, soil water content, and dissolved organic carbon) and soil microorganisms (community, soil bacterial, and soil fungal PLFAs) on the variance in basal respiration. We first deleted the collinear variables and subsequently constructed a full model based on the standard with $\triangle$ AIC $<2$ with MuMIn and performance packages in R. The parameter coefficients were used to calculate the relative effect of each predictor on basal respiration. All statistical analyses were performed with $\mathrm{R}$ version 3.3.2 ( $\mathrm{R}$ Core Team 2016).

\section{Results}

\section{Responses of plants and soil properties to rodent} exclusion

Plant abundance ( $T=2.72, P=0.01$, Fig. 2a) and plant species richness $(T=2.47, P=0.02$, Fig. $2 \mathrm{~b})$ were significantly greater with rodent exclusion than without rodent exclusion. Abundance increased by $59 \%$, and richness increased by $31 \%$ when rodents were excluded.

Soil organic carbon content and most soil properties were not significantly affected by rodent exclusion (Table 1). Rodent exclusion, however, significantly decreased urease activity (Table 1$)$. Bacterial PLFAs ( $T=$ 4.07, $P=0.001$, Fig. 3a), fungal PLFAs $(T=3.17, P=0.006$, Fig. 3b), and total PLFAs ( $T=3.95, P=0.001$, Fig. $3 d$ ) were significantly lower in the rodent exclusion plots than in the plots without exclusion. Relative to the non-exclusion plots, rodent exclusion reduced numbers of bacterial, fungal, and total PLFAs by $19 \%, 21 \%$, and $17 \%$, respectively. In contrast, the ratio of fungi to bacteria $(T=2.83, P=$ 0.01 , Fig. $3 c$ ) was significantly higher with than without rodent exclusion.

\section{Responses of soil basal respiration to rodent exclusion}

Basal respiration ( $T=4.87, P=0.005$, Fig. 4a) was significantly lower (by $15 \%$ ) with than without rodent exclusion. Substrate-induced respiration $(T=0.34, P=0.75$, Fig. 4b) was not significantly affected by rodent exclusion. The ratio of basal respiration to substrate-induced respiration was significantly lower with than without rodent exclusion ( $T=3.21, P=0.02$, Fig. $4 \mathrm{c})$.

A multiple regression model indicated that most of the variance in basal respiration was explained by soil 

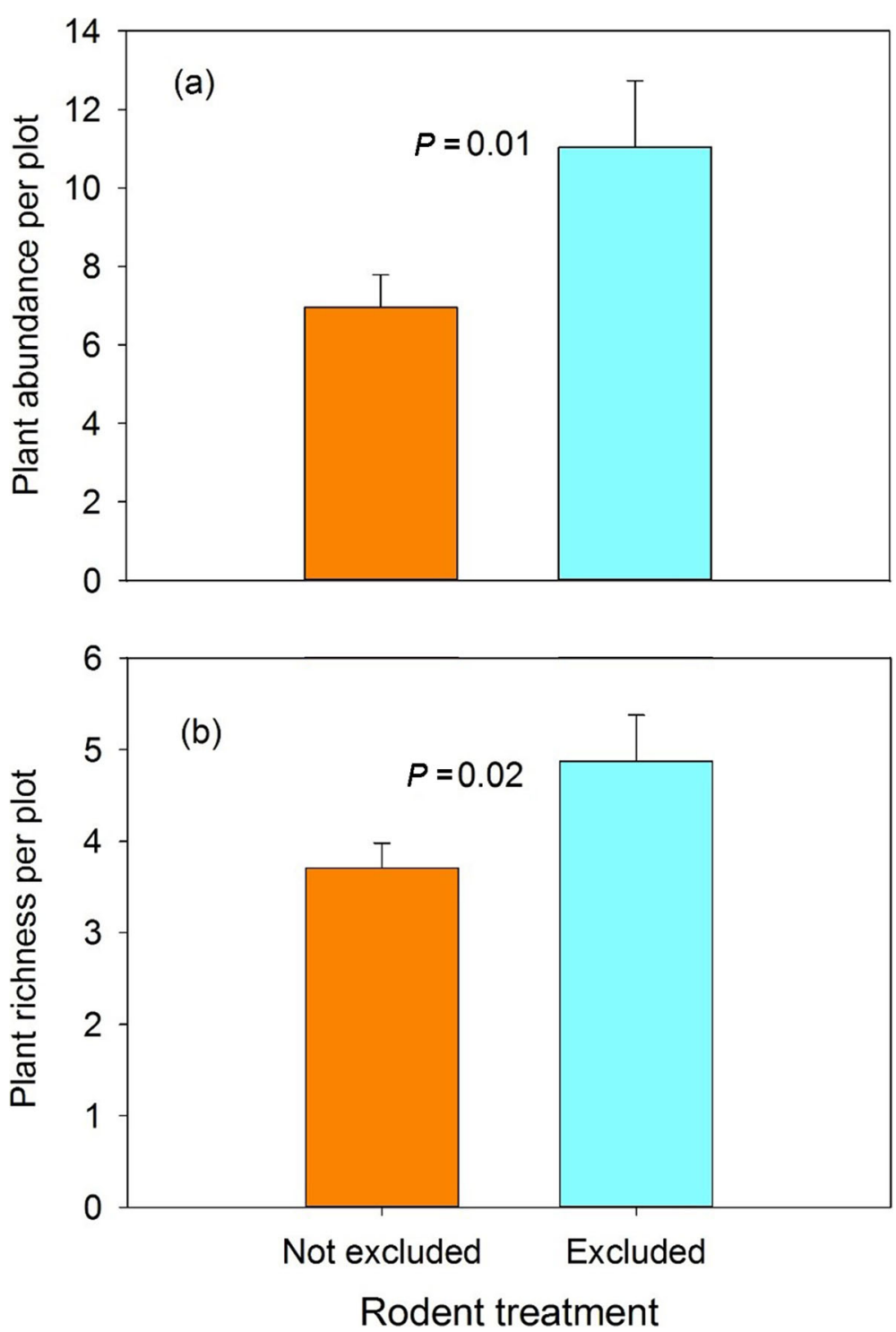

Fig. 2 Plant abundance (a) and plant species richness (b) per plot with and without rodent exclusion. Values are means $\pm S E, n=24$

properties and soil microbial properties and especially by the microbial community composition (ratio of fungi to bacteria) (Fig. 5). The total effects of plant properties and soil enzymes on basal respiration were marginal.

\section{Discussion}

Rodents strongly affect plant regeneration and community composition in forest ecosystems by their scatterhoarding of seeds and by changing plant-plant interactions (Kang et al. 2020; Yang et al. 2020). In the current study, we examined the indirect effects of rodents on carbon emission from soil after a heavy snowfall. Heavy snowfalls can reduce seed production by breaking branches and limbs. Consequently, plant-predator (seed consumer) interactions would be altered (Mundim and
Bruna 2016) and increase the percentage of seeds consumed by predators (Zhou et al. 2013). Consistent with our hypothesis, plant abundance and species richness were significantly enhanced by rodent exclusion. Based on the increase in plant regeneration, we expected that exclusion would increase carbon input into the soil and increase soil organic carbon content given the tight linkages between above- and belowground systems (Bardgett and Wardle 2003; Wardle and Zackrisson 2005). However, soil organic carbon content was not significantly increased by rodent exclusion (Table 1). The failure of rodent exclusion to increase soil organic carbon content might be explained by the high levels carbon in the soil of our study site. Also, our study covered only 3 years; perhaps a longer study would have revealed a positive 
Table 1 Soil properties and enzyme activities in plots without and with rodent exclusion. Values are means $\pm S E, n=24$. Means in a row are not significantly different except for urease activity $(P<0.05)$

\begin{tabular}{lll}
\hline Variable & Without rodent exclusion & With rodent exclusion \\
\hline Soil organic carbon $(\mathrm{SOC}, \%)$ & $15.02 \pm 0.59$ & $15.37 \pm 0.66$ \\
Total nitrogen $(\mathrm{TN}, \%)$ & $1.10 \pm 0.04$ & $1.13 \pm 0.04$ \\
SOC: TN & $13.73 \pm 0.21$ & $13.57 \pm 0.25$ \\
Soil water content (\%) & $50.59 \pm 0.66$ & $50.64 \pm 0.71$ \\
$\mathrm{pH}$ & $4.45 \pm 0.12$ & $4.68 \pm 0.13$ \\
Dissolved organic carbon $\left(\mathrm{mg} \cdot \mathrm{kg}^{-1}\right)$ & $167.68 \pm 12.39$ \\
$\mathrm{NH}_{4}{ }^{-} \mathrm{N}\left(\mathrm{mg} \cdot \mathrm{kg}^{-1}\right)$ & $178.98 \pm 10.83$ & $1.70 \pm 0.15$ \\
$\mathrm{NO}^{-}{ }_{3} \mathrm{~N}(\mathrm{mg} \cdot \mathrm{kg}$ & \\
Cellulase activity $\left(\mu \mathrm{g} \cdot \mathrm{g}^{-1} \cdot \mathrm{h}^{-1}\right)$ & $2.01 \pm 0.15$ & $6.42 \pm 0.77$ \\
Sucrase activity $\left(\mu \mathrm{g} \cdot \mathrm{g}^{-1} \cdot \mathrm{h}^{-1}\right)$ & $7.72 \pm 1.00$ & $9.68 \pm 0.95$ \\
Urease activity $\left(\mathrm{mg} \cdot \mathrm{g}^{-1} \cdot \mathrm{d}^{-1}\right)$ & $10.44 \pm 0.77$ & $113.91 \pm 6.65$ \\
\hline
\end{tabular}

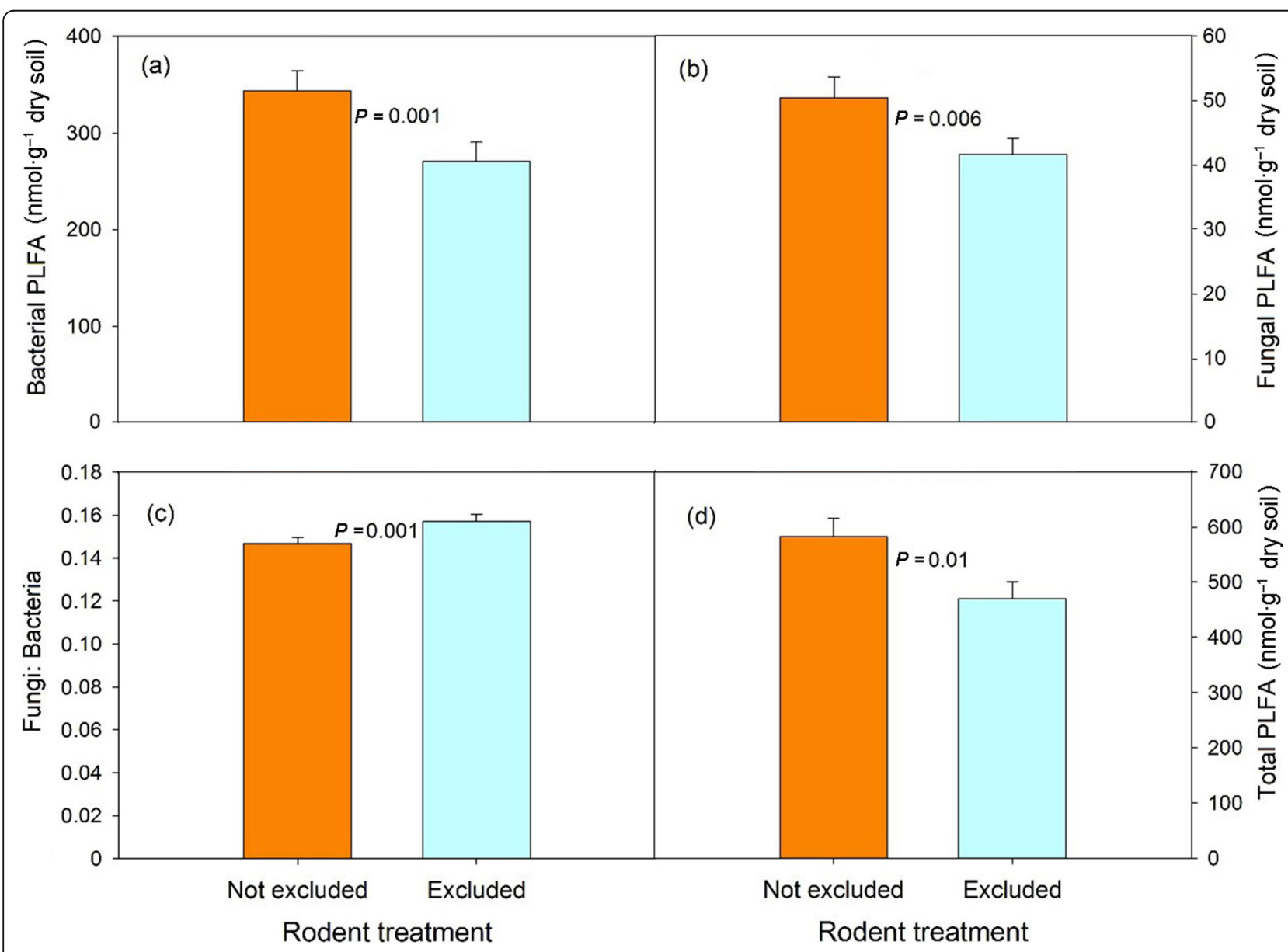

Fig. 3 Bacterial PLFAs (a), fungal PLFAs (b), fungal:bacterial PLFAs (c), and total PLFAs (d) with and without rodent exclusion. Values are means \pm $\mathrm{SE}, n=22$ or 24 

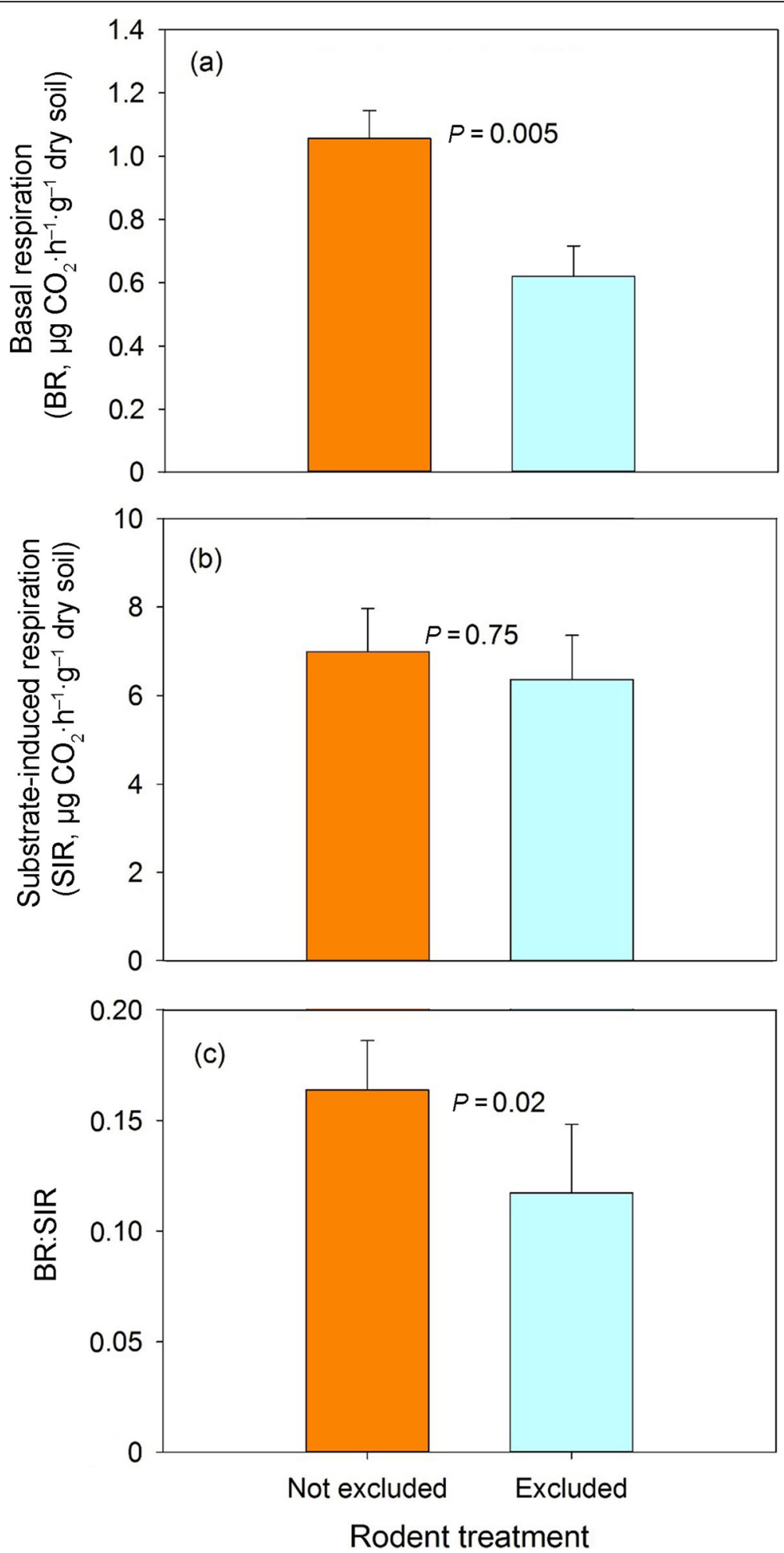

Fig. 4 Basal respiration (a), substrate-induced respiration (b), and their ratios (c) with and without rodent exclusion. Values are mean $\pm S E, n=6$ 


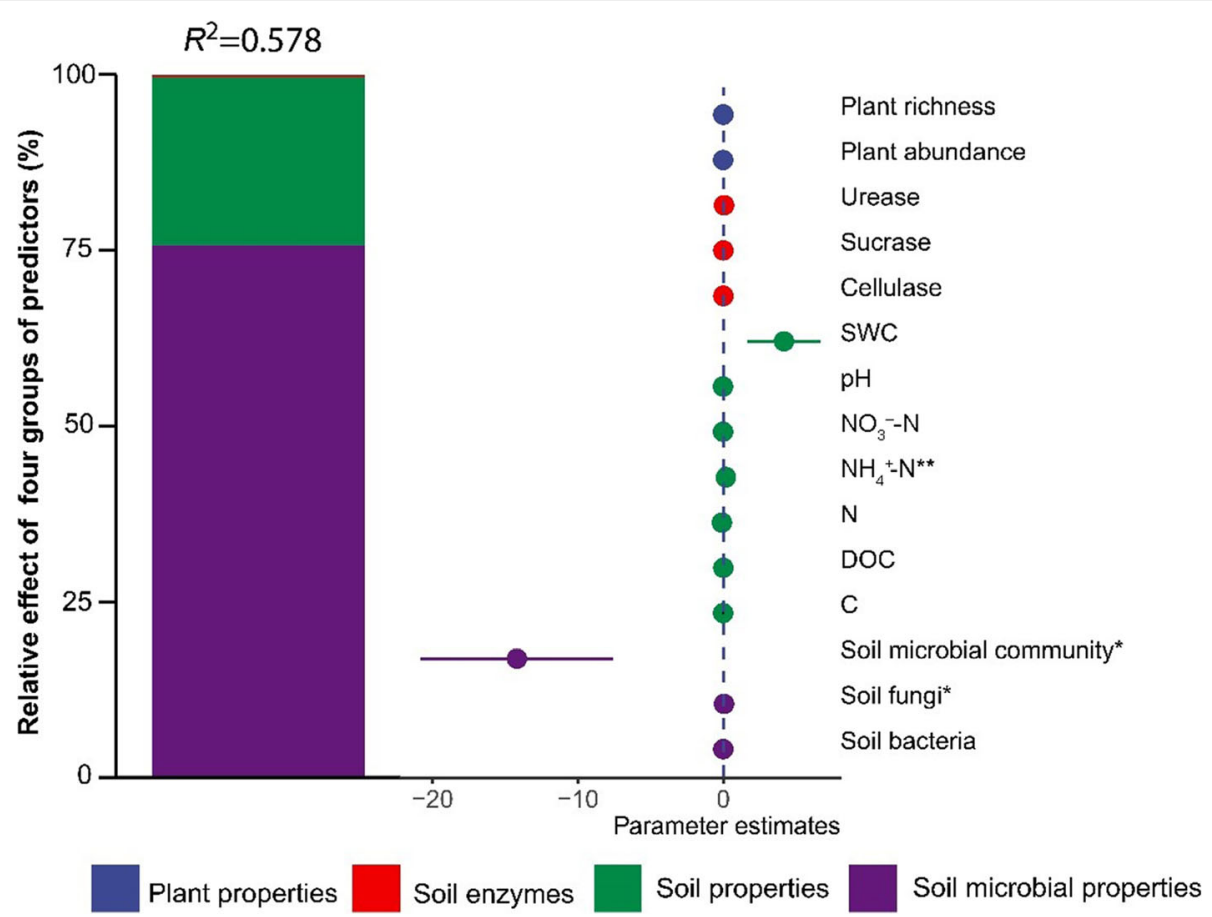

Fig. 5 Relative contribution of factors to basal respiration by using multiple regression model. The factors were divided into four groups of predictors (plant properties, soil enzymes, soil properties, and soil microbial properties). The relative contribution of four groups were calculated as the sum of the standardized regression coefficients for each group. The averaged parameter estimates of multiple predictors were obtained from standardized coefficients. Components of the four groups of predictors are indicated by colored symbols on the right side of the figure; the lines through the symbols indicate the range of the effects. SWC = soil water content. DOC = dissolved organic carbon content

effect of rodent exclusion on soil organic carbon content. Since evergreen broad-leaved forest are susceptible to extreme snow in the subtropical regions (Ge et al. 2015).

We found that rodent exclusion significantly decreased soil microbial biomass, which was inconsistent with our hypothesis and also with previous findings that increases in plant diversity increased soil microbial biomass (Jing et al. 2015; Lange et al. 2015). The significant difference in soil microbial biomass and community composition between plots with and without rodent exclusion has at least two possible explanations. First, increases in plant abundance and species richness in rodent exclusion plots may have increased plant uptake of nutrients and thereby increased the competition for nutrients experienced by soil microorganisms (Ullah et al. 2019; Wu et al. 2011). Second, plant seeds of canopy trees usually contain tannin, no matter the seed size is large or small (Wang et al. 2013; Yang et al. 2020), which may have suppressed soil microbial activity to a greater degree in plots with than without rodent exclusion.

Consistent with the decline in soil microbial biomass, soil basal respiration was significantly lower with than without rodent exclusion. According to multiple regression analysis, the major factor affecting soil basal respiration was the composition of the soil microbial community. Positive relationships between soil basal respiration and microbial biomass carbon were also reported in other ecosystems (Lange et al. 2015; Wardle and Zackrisson 2005). Although rodent exclusion reduced soil basal respiration, it did not significantly affect substrate-induced respiration, perhaps because of the high background level of carbon in the soil. A decrease in soil basal respiration has the potential to increase soil carbon sequestration over the long term. Another experiment at the same study site also found that net ecosystem $\mathrm{CO}_{2}$ exchange and ecosystem respiration were strongly decreased by heavy snow in 2015 but then sharply increased in 2016 (Song et al. 2017a), which supported our results.

Based on our camera trap surveys (unpublished data), some other mammals have been occasionally detected (e.g., muntjacs and boars) although small rodents are the dominant floor animals in our study forest. Nevertheless, our enclosure treatment excluded all kinds of floor animals, and there faeces may potentially affect the soil properties. Furthermore, the enclosure may have little effects on light penetration, air flow, temperature, and moisture, because of the relatively large openings in the mesh. Scatter-hoarding rodents play an important role on seedling regeneration in our study forest via seed predation and seed dispersal (Lang and Wang 2016). As we 
suggested earlier in the Discussion that heavy snowfall is likely to increase the percentage of seeds consumed by rodents, such that the effects of rodents on plant regeneration would differ depending on whether or not exclusion occurred after a heavy snowfall. In addition, the dominant herbivores in our study forest were insects (unpublished data of herbivory survey), so the effect of rodents on seedling damage can be ignored. Therefore, the effects of enclosure on seedling regeneration may mainly depend on seed predation and dispersal by rodents.

\section{Conclusions}

This study presented plant-rodent interactions after heavy snowfall in an old growth forest. We compared plots with and without rodent exclusion following a heavy snowfall in an old forest. There were three main ecological outputs. First, rodent exclusion enhanced plant regeneration (as indicated by increased plant species richness and abundance). Second, soil basal respiration was strongly decreased by rodent exclusion, which indicates that plant-rodent interactions indirectly affect soil carbon dynamics. Third, the main factor associated with the decrease in soil basal respiration and therefore with the potential for increased soil carbon sequestration in rodent-exclusion plots was the composition of the soil microbial community, which in turn was regulated by plants. The above conclusions and implications produced by this study can be important for sustainable forest management in face of extreme snow storm in future.

\section{Supplementary Information}

The online version contains supplementary material available at https://doi. org/10.1186/s40663-021-00310-2.

Additional file 1: Figure S1. Field experimental plots setting after extreme snow event in 2015. The up one means the conceptual figure of experiment design, the below ones show the mesh on the field plot.

\section{Acknowledgments}

We thank Zhiyun Lu and Hangdong Wen from the Ailaoshan Station for Subtropical Forest Ecosystem Studies for their field assistance. We also thank three anonymous reviewers for their insightful comments.

\section{Authors' contributions}

BW and JW acquired the funding and designed the experiment. QZ, JW, SX, ZC, BW, and DL collected and analyzed the data. The authors jointly contributed to the writing of the manuscript and approved the final manuscript.

\section{Funding}

This research was funded by National Natural Science Foundation of China (Nos. 31971497, 31971444), by Yunnan Key Laboratory of Plant Reproductive Adaptation and Evolutionary Ecology and Yunnan University (No. (176210103).

\section{Availability of data and materials}

The datasets used and/or analyzed during the current study are available from the corresponding author on reasonable request.

\section{Declarations}

Ethics approval and consent to participate

Not applicable.

\section{Consent for publication}

Not applicable.

\section{Competing interests}

The authors declare no competing interests.

\section{Author details}

${ }^{1}$ Yunnan Key Laboratory of Plant Reproductive Adaptation and Evolutionary Ecology, Yunnan University, Kunming 650500, China. ${ }^{2}$ Key Laboratory of Soil Ecology and Health in Universities of Yunnan Province, School of Ecology and Environmental Sciences, Yunnan University, Kunming 650500, China. ${ }^{3}$ Xishuangbanna Tropical Botanical Garden, Chinese Academy of Sciences, Mengla 666303, China. ${ }^{4}$ School of Resources and Environmental Engineering, Anhui University, Hefei 230601, China.

Received: 10 January 2021 Accepted: 27 April 2021

Published online: 17 May 2021

\section{References}

Ashley WS, Haberlie AM, Gensini VA (2020) Reduced frequency and size of latetwenty-first-century snowstorms over North America. Nat Clim Chang 10(6): 539-544. https://doi.org/10.1038/s41558-020-0774-4

Bardgett RD, Caruso T (2020) Soil microbial community responses to climate extremes: resistance, resilience and transitions to alternative states. Philos Trans R Soc B-Biol Sci 375(1794):20190112. https://doi.org/10.1098/rstb.2019.0112

Bardgett RD, Hobbs PJ, Frostegård A (1996) Changes in soil fungal:bacterial biomass ratios following reductions in the intensity of management of an upland grassland. Biol Fertil Soils 22(3):261-264. https://doi.org/10.1007/ BF00382522

Bardgett RD, van der Putten WH (2014) Belowground biodiversity and ecosystem functioning. Nature 515(7528):505-511. https://doi.org/10.1038/nature13855

Bardgett RD, Wardle DA (2003) Herbivore-mediated linkages between aboveground and belowground communities. Ecology 84(9):2258-2268. https://doi.org/10.1890/02-0274

Boone SR, Mortelliti A (2019) Small mammal tree seed selection in mixed forests of the eastern United States. Forest Ecol Manage 449:117487. https://doi. org/10.1016/j.foreco.2019.117487

Cao L, Wang Z, Yan C, Chen J, Guo C, Zhang Z (2016) Differential foraging preferences on seed size by rodents result in higher dispersal success of medium-sized seeds. Ecology 97(11):3070-3078. https://doi.org/10.1002/ecy.1555

Contosta AR, Burakowski EA, Varner RK, Frey SD (2016) Winter soil respiration in a humid temperate forest: the roles of moisture, temperature, and snowpack. J Geophys Res-Biogeosci 121(12):3072-3088. https://doi.org/10.1002/201 6JG003450

Core Team R (2016) R: a language and environment for statistical computing. R Foundation for Statistical Computing, Vienna

Diaz-Yanez O, Mola-Yudego B, Ramon Gonzalez-Olabarria J, Pukkala T (2017) How does forest composition and structure affect the stability against wind and snow? Forest Ecol Manage 401:215-222. https://doi.org/10.1016/j.foreco.2017. 06.054

Fei SL, Jo I, Guo QF, Wardle DA, Fang JY, Chen AP, Oswalt CM, Brockerhoff EG (2018) Impacts of climate on the biodiversity-productivity relationship in natural forests. Nat Commun 9(1):5436. https://doi.org/10.1038/s41467-01807880-w

Frostegård Å, Bååth E (1996) The use of phospholipid fatty acid analysis to estimate bacterial and fungal biomass in soil. Biol Fertil Soils 22(1-2):59-65. https://doi.org/10.1007/BF00384433

Frostegård A, Tunlid A, Bååth E (2011) Use and misuse of PLFA measurements in soils. Soil Biol Biochem 43(8):1621-1625. https://doi.org/10.1016/j.soilbio.201 0.11 .021

Ge J, Xiong G, Wang Z, Zhang M, Zhao C, Shen G, Xu W, Xie Z (2015) Altered dynamics of broad-leaved tree species in a Chinese subtropical montane mixed forest: the role of an anomalous extreme 2008 ice storm episode. Ecol Evol 5(7):1484-1493. https://doi.org/10.1002/ece3.1433

Jactel H, Gritti ES, Drossler L, Forrester DI, Mason WL, Morin X, Pretzsch $H_{1}$ Castagneyrol B (2018) Positive biodiversity-productivity relationships in 
forests: climate matters. Biol Lett 14(4):20170747. https://doi.org/10.1098/ rsbl.2017.0747

Jing X, Sanders NJ, Shi Y, Chu H, Classen AT, Zhao K (2015) The links between ecosystem multifunctionality and above- and belowground biodiversity are mediated by climate. Nat Commun 6(1):8159. https://doi.org/10.1038/ ncomms9159

Kang H, Chang M, Liu S, Chao Z, Zhang X, Wang D (2020) Rodent-mediated plant community competition: what happens to the seeds after entering the adjacent stands? Forest Ecosyst 7(1):56. https://doi.org/10.1186/s40663-02000270-z

Kayler ZE, De Boeck HJ, Fatichi S, Gruenzweig JM, Merbold L, Beier C, McDowell N, Dukes JS (2015) Experiments to confront the environmental extremes of climate change. Front Ecol Environ 13(4):219-225. https://doi.org/10.1890/14 0174

Keenan RJ, Reams GA, Achard F, de Freitas JV, Grainger A, Lindquist E (2015) Dynamics of global forest area: results from the FAO global forest resources assessment 2015. For Ecol Manag 352:9-20. https://doi.org/10.1016/jforeco.2 015.06 .014

Lang ZW, Wang B (2016) The effect of seed size on seed fate in a subtropical forest, southwest of China. iForest-Biogeosci For 9:652-657

Lange M, Eisenhauer N, Sierra CA, Bessler H, Engels C, Griffiths Rl, MelladoVazquez PG, Malik AA, Roy J, Scheu S, Steinbeiss S, Thomson BC, Trumbore SE, Gleixner G (2015) Plant diversity increases soil microbial activity and soil carbon storage. Nat Commun 6(1):6707. https://doi.org/10.1038/ncomms7707

Lehtonen I, Kamarainen M, Gregow H, Venalainen A, Peltola H (2016) Heavy snow loads in Finnish forests respond regionally asymmetrically to projected climate change. Nat Hazards Earth Syst Sci 16(10):2259-2271. https://doi. org/10.5194/nhess-16-2259-2016

Li W, Wu J, Bai E, Jin C, Wang A, Yuan F, Guan D (2016) Response of terrestrial carbon dynamics to snow cover change: a meta-analysis of experimental manipulation (II). Soil Biol Biochem 103:388-393. https://doi.org/10.1016/j. soilbio.2016.09.017

Liu G (1996) Soil physical and chemical analysis and description of soil profiles. China Standard Press, Beijing (in Chinese)

Luyssaert S, Schulze ED, Börner A, Knohl A, Hessenmöller D, Law BE, Ciais P, Grace J (2008) Old-growth forests as global carbon sinks. Nature 455(7210): 213-215. https://doi.org/10.1038/nature07276

Morales-Hidalgo D, Oswalt SN, Somanathan E (2015) Status and trends in global primary forest, protected areas, and areas designated for conservation of biodiversity from the global forest resources assessment 2015. Forest Ecol Manage 352:68-77. https://doi.org/10.1016/j.foreco.2015.06.011

Mundim FM, Bruna EM (2016) Is there a temperate bias in our understanding of how climate change will alter plant-herbivore interactions? A meta-analysis of experimental studies. Am Nat 188(S1):S74-S89. https://doi.org/10.1086/ 687530

Pan Y, Birdsey RA, Fang J, Houghton R, Kauppi PE, Kurz WA, Phillips OL, Shvidenko A, Lewis SL, Canadell JG, Ciais P, Jackson RB, Pacala SW, McGuire AD, Piao S, Rautiainen A, Sitch S, Hayes D (2011) A large and persistent carbon sink in the world's forests. Science 333(6045):988-993. https://doi. org/10.1126/science.1201609

Peltola H, Nykanen ML, Kellomaki S (1997) Model computations on the critical combination of snow loading and windspeed for snow damage of scots pine, Norway spruce and birch sp. at stand edge. Forest Ecol Manage 95(3): 229-241. https://doi.org/10.1016/S0378-1127(97)00037-6

Reyer CPO, Brouwers N, Rammig A, Brook BW, Epila J, Grant RF, Holmgren M, Langerwisch F, Leuzinger S, Lucht W, Medlyn B, Pfeifer M, Steinkamp J, Vanderwel MC, Verbeeck H, Villela DM (2015) Forest resilience and tipping points at different spatio-temporal scales: approaches and challenges. J Ecol 103(1):5-15. https://doi.org/10.1111/1365-2745.12337

Sitters J, Venterink HO (2015) The need for a novel integrative theory on feedbacks between herbivores, plants and soil nutrient cycling. Plant Soil 396(1-2):421-426. https://doi.org/10.1007/s11104-015-2679-y

Song QH, Fei XH, Zhang YP, Sha LQ, Wu CS, Lu ZY, Luo K, Zhou WJ, Liu YT, Gao $J B$ (2017a) Snow damage strongly reduces the strength of the carbon sink in a primary subtropical evergreen broadleaved forest. Environ Res Lett 12: 104014

Song X, Hogan JA, Brown C, Cao M, Yang J (2017b) Snow damage to the canopy facilitates alien weed invasion in a subtropical montane primary forest in southwestern China. Forest Ecol Manage 391:275-281. https://doi.org/10.101 6/j.foreco.2017.02.031
Stephenson NL, Das AJ, Condit R, Russo SE, Baker PJ, Beckman NG, Coomes DA, Lines ER, Morris WK, Rüger N, Álvarez E, Blundo C, Bunyavejchewin S, Chuyong G, Davies SJ, Duque A, Ewango CN, Flores O, Franklin JF, Grau HR, Hao Z, Harmon ME, Hubbell SP, Kenfack D, Lin Y, Makana JR, Malizia A, Malizia LR, Pabst RJ, Pongpattananurak N, Su SH, Sun IF, Tan S, Thomas D, van Mantgem PJ, Wang X, Wiser SK, Zavala MA (2014) Rate of tree carbon accumulation increases continuously with tree size. Nature 507(7490):90-93. https://doi.org/10.1038/nature12914

Tan ZH, Zhang YP, Schaefer D, Yu GR, Liang N, Song QH (2011) An old-growth subtropical Asian evergreen forest as a large carbon sink. Atmos Environ 45(8):1548-1554. https://doi.org/10.1016/..atmosenv.2010.12.041

Ullah S, Muhammad B, Amin R, Haider AH (2019) Sensitivity of Arbuscular mycorrhizal fungi in old-growth forest: direct effect on growth and soil carbon storage. Appl Ecol Environ Res J 17:13749-13758

Venalainen A, Lehtonen I, Laapas M, Ruosteenoja K, Tikkanen OP, Viiri H, Ikonen VP, Peltola H (2020) Climate change induces multiple risks to boreal forests and forestry in Finland: a literature review. Glob Chang Biol 26(8):4178-4196. https://doi.org/10.1111/gcb.15183

Wang B, Philips JS, Tomlinson KW (2013) Tradeoff between physical and chemical defense in plant seeds is mediated by seed mass. Oikos 127:440-447

Wang B, Philips JS, Tomlinson KW (2013a) Tradeoff between physical and chemical defense in plant seeds is mediated by seed mass. Oikos 127:440-447

Wang B, Ye CX, Cannon CH, Chen J (2013b) Dissecting the decision making process of scatter-hoarding rodents. Oikos 122(7):1027-1034. https://doi. org/10.1111/j.1600-0706.2012.20823.x

Wardle DA, Zackrisson O (2005) Effects of species and functional group loss on island ecosystem properties. Nature 435(7043):806-810. https://doi.org/10.103 8/nature03611

Wu J, Liu Z, Chen D, Huang G, Zhou L, Fu S (2011) Understory plants can make substantial contributions to soil respiration: evidence from two subtropical plantations. Soil Biol Biochem 43(11):2355-2357. https://doi.org/10.1016/j. soilbio.2011.07.011

Xu J, Xue L, Su Z (2016) Impacts of forest gaps on soil properties after a severe ice storm in a Cunninghamia lanceolata stand. Pedosphere 26(3):408-416. https://doi.org/10.1016/S1002-0160(15)60053-4

Yang X, Yan C, Gu H, Zhang Z (2020) Interspecific synchrony of seed rain shapes rodent-mediated indirect seed-seed interactions of sympatric tree species in a subtropical forest. Ecol Lett 23(1):45-54. https://doi.org/10.1111/ele.13405

Zhao CY, Fang YH, Luo Y, Wang J (2016) Interdecadal component variation characteristics in heavy winter snow intensity in north-eastern China and its response to sea surface temperatures. Atmos Res 180:165-177. https://doi, org/10.1016/j.atmosres.2016.05.016

Zhou G, Liu S, Li Z, Zhang D, Tang X, Zhou C, Yan J, Mo J (2006) Old-growth forests can accumulate carbon in soils. Science 314(5804):1417. https://doi. org/10.1126/science.1130168

Zhou Y, Newman C, Chen J, Xie Z, Macdonald DW (2013) Anomalous, extreme weather disrupts obligate seed dispersal mutualism: snow in a subtropical forest ecosystem. Glob Chang Biol 19(9):2867-2877. https://doi.org/10.1111/ gcb. 12245

\section{Submit your manuscript to a SpringerOpen ${ }^{\circ}$ journal and benefit from:}

- Convenient online submission

- Rigorous peer review

- Open access: articles freely available online

- High visibility within the field

- Retaining the copyright to your article

Submit your next manuscript at $\boldsymbol{\nabla}$ springeropen.com 